\title{
Narcissus serotinus Loefl. ex L. (Amaryllidaceae), confirmed for the province of Cádiz (Andalusia, Spain)
}

\author{
Javier López-Tirado ${ }^{2} \&$ Javier González-Armenteros² \\ 'Department of Integrated Sciences, Faculty of Experimental Sciences, University of Huelva, Avda. Tres de Marzo s.n., \\ 21071 Huelva (Spain). \\ ${ }^{2} \mathrm{C} /$ Ebanista Soto Moreno 2, 4a 2, 14010 Córdoba (Spain).
}

\author{
Correspondencia \\ J. López-Tirado \\ e-mail: javier.lopez@dbasp.uhu.es \\ Recibido: 15 enero 2019 \\ Aceptado: 2 septiembre 2019 \\ Publicado on-line: 25 septiembre 2019 \\ Editado por: B. Cabezudo
}

\begin{abstract}
Narcissus serotinus Loefl. ex L. (Amaryllidaceae), especie confirmada para la provincia de Cádiz (Andalucía, España)
\end{abstract}

Key words: Chorology, Amaryllidaceae, Narcissus serotinus, Cádiz.

Palabras clave: Corología, Amaryllidaceae, Narcissus serotinus, Cádiz.
Narcissus serotinus Loefl. ex L. and N. obsoletus (Haw.) Steud. have been actively mistaked. This fact can be stated in Valdés (1987); N. serotinus was catalogued as a very common species in most of western Andalusia whilst $N$. obsoletus was either dismissed or more feasibly included in the former. Something similar happened in eastern Andalusia, where only N. obsoletus inhabits, which has been commonly confused with $N$. serotinus (Navarro 2009). More recently, the distribution of both species has been clarified. Narcissus serotinus grows in southwestern Iberian Peninsula (Badajoz, Cáceres, Córdoba, Huelva and Seville in Spain; Alentejo and Algarve in Portugal), whereas $N$. obsoletus does it in southern and eastern Spain (Alicante, Almería, Barcelona, Cádiz, Castellón, Córdoba, Gerona, Huelva, Málaga, Murcia, Seville, Teruel, Valencia and Balearic Islands) according to Aedo (2013).
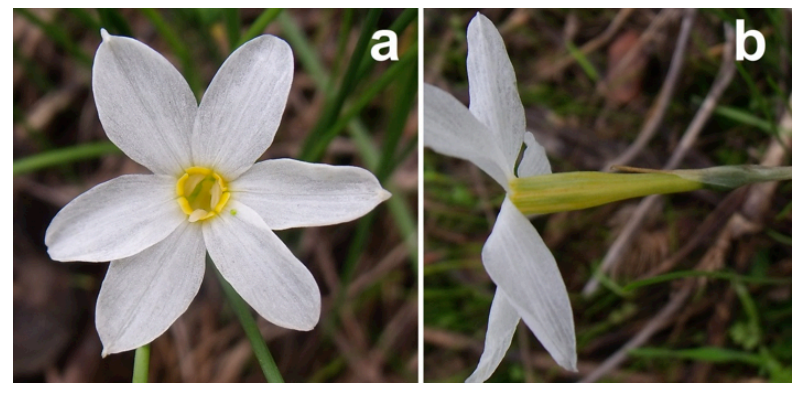

Figure 1. Front (a) and lateral (b) view of $N$. serotinus in the new population. Vista lateral (a) y frontal (b) de $N$. serotinus en la nueva localidad.
Considering records from www.anthos.es (last access August 2019), there is a herbarium sheet from 1956 which has been recently revised and identified by Aedo as $N$. serotinus in the province of Cádiz (CÁDIZ. Villamartín, [30STF68], XI-1956, s.c., (GDA 187)). Herbarium specimens from this province, and classified as $N$. serotinus or $N$. obsoletus from SEV, have been revised by the authors; all of them belonging to the latter (see Annex I). Therefore, the current work confirms the presence of $N$. serotinus in the province of Cádiz, whose last collection was in 1956. Information about the new finding is given below as follows:

CÁDIZ. Villamartín: Santa Lucía [30STF7084], 174 m, 13-XI-2018, J. López Tirado s.n. (COFC 66116).

The target locality has been found in the northern area close to Seville province. It is composed of hundreds of specimens in a high density. Most of them were fructifying when found; one flowering plant was collected (Fig. 1) and deposited in the Herbarium of the Faculty of Sciences of Córdoba (COFC). This is probably the southernmost population in the Iberian Peninsula.

\section{Annex I}

CÁDIZ. A $3 \mathrm{Km}$ de El Algar, 02-XI-1979 (SEV 93797). CÁDIZ. Puerto de Santa María: Carretera de San Fernando; en prados salobres, 31-X-1967 (SEV 5894). CÁDIZ. Arcos de la Frontera, 14-X-1980 (SEV 93730). CÁDIZ. Sanlúcar de Barrameda, pinar de la Algaida, 02XI-1978 (SEV 41686). CÁDIZ. San José del Valle, 02XI-1979 (SEV 93779). CÁDIZ. Puerto de Santa María: Carretera de San Fernando; en prados salobres, 31-X- 
1967 (SEV 7729). CÁDIZ. Trebujena, cortijo El Vento, marismas, 01-X-1973 (SEV 19761). CÁDIZ. Chipiona, pinar Pinus pinea, 03-XI-1978 (SEV 41798). CÁDIZ. Entre Estepa y Bornos, bordes de cunetas, 11-XI-1977 (SEV 93727). CÁDIZ. San Roque, in short grass, edge of cultivation, 12-X-1977 (SEV 89855). CÁDIZ. San Roque, El Almendral, 12-X-1977 (SEV 83069). CÁDIZ. Entre Espera y Arcos, a $6 \mathrm{Km}$ de Espera, 02-XI-1979 (SEV 93798). CÁDIZ. Puerto de Santa María, 03-XI-1978 (SEV 93792).

\section{Acknowledgements}

To Rafael Díez Domínguez for suggesting us the area to look for this autumnal daffodil. To María Jesús
Ariza Molina for providing us the herbarium sheets from SEV.

\section{Bibliografía}

Aedo, C. (2013). Narcissus L. In, S. Castroviejo et al. (eds.) Flora Iberica, XX (pp. 340-397). Madrid: Departamento de Publicaciones del CSIC.

Navarro, F.B. (2009). Amaryllidaceae. In, G. Blanca et al. (eds.) Flora Vascular de Andalucía Oriental, 1 (pp. 169-181). Sevilla: Consejería de Medio Ambiente, Junta de Andalucía.

Valdés, B. (1987). Narcissus L. In, B. Valdés et al. (eds.) Flora Vascular de Andalucía Occidental, 3 (pp. 463474). Barcelona: Ketres Editora S.A. 